https://helda.helsinki.fi

Finländska svensklärares undervisningspraktiker och deras

samband med elevers inlärningsresultat

\title{
Huhtala, Anne
}

2019

Huhtala , A , Vesalainen , M , Hildén , R \& Rautopuro , J 2019 , ' Finländska svensklärares undervisningspraktiker och deras samband med elevers inlärningsresultat ' , Nordand, vol. 14 , nr. 1 , s. 4-24 . https://doi.org/10.18261/issn.2535-3381-2019-01-01

http://hdl.handle.net/10138/304935

https://doi.org/10.18261/issn.2535-3381-2019-01-01

unspecified

acceptedVersion

Downloaded from Helda, University of Helsinki institutional repository.

This is an electronic reprint of the original article.

This reprint may differ from the original in pagination and typographic detail.

Please cite the original version. 
Finländska svensklärares undervisningspraktiker och deras samband med elevers inlärningsresultat

The instructional practices of Finnish teachers of Swedish and their connection to students' learning outcomes

Anne Huhtala

Helsingfors universitet

anne.huhtala@helsinki.fi

Marjo Vesalainen

Helsingfors universitet

marjo.vesalainen@helsinki.fi

Raili Hildén

Helsingfors universitet

raili.hilden@helsinki.fi

Juhani Rautopuro

Jyväskylä universitet

juhani.rautopuro@jyu.fi

Lärarens val av undervisningspraktiker spelar en avgörande roll för elevers inlärningsresultat. I lärarkognitionen ingår förmågan att på adekvata sätt styra och handleda elevens inlärningsprocess och utvärdera dess utgång med livslångt lärande som huvudsyfte. I artikeln kartläggs och analyseras vilka samband som finns mellan undervisningspraktiker och elevers inlärningsresultat i svenskans långa lärokurs i slutet av den grundläggande utbildningen. Materialsamplet härstammar från den finländska nationella utvärderingen från 2013 och omfattar 1679 elever och 98 lärare, vars respons genomgick en fördjupad analys. Ur analysen framgick en tämligen traditionell bild av lärarnas arbetssätt. Vissa tidsenliga undervisningspraktiker som muntlig parövning var vanliga, medan bedömningsmönstren tedde sig relativt traditionella med skriftlig produktion i fokus. I princip uppskattade lärarna dock allmänna pedagogiska mål, t.ex. att växa som människa och att bemöta andra kulturer. En del signifikanta samband upptäcktes mellan arbetssätt och elevers språkfärdigheter. Skolundervisningens betydelse var tydligare för pojkar än för flickor. Barn till högre utbildade föräldrar gynnades mest av tidsenliga arbetssätt. Sammanfattningsvis 
rekommenderas en fortsatt förnyelse av svenskundervisningens praktiker genom pedagogiskt motiverad användning av informationsteknologi och utökande av autentiskt språkbruk i genuina möten eller på distans. I synnerhet bör pojkar och barn till dem som inte tagit studentexamen beaktas.

Nyckelord: svenska som det andra inhemska språket, undervisningspraktiker, inlärningsresultat, nationella utvärderingar, bedömning 
Teachers' choice of instructional practices plays a fundamental role in students' achievement of intended learning outcomes. Teacher competence implies the ability to guide students' learning process and to evaluate its outcome with regard to lifelong learning. In this article, we describe and analyse connections between teaching practices reported by teachers of Swedish in Finnish schools in Finland and the learning outcomes of their students by the end of compulsory basic education. The data come from the Finnish national evaluation of learning outcomes that was carried out in 2013, comprising responses from 1679 students and 98 teachers from 73 schools. The results of the quantitative and qualitative analyses revealed a rather traditional landscape of Swedish language teaching. Certain communicative teaching practices were reported. Yet, written production was favoured in assessments. In principle, teachers embraced more comprehensive pedagogical goals, such as personal development and cultural diversity. A few statistically significant connections were documented between teaching practices and students' Swedish language skills. Language instruction seemed to have a stronger impact on boys' language skills than on girls', and children with more welleducated parents benefitted more from up-to-date practices than those of lower educated parents. In conclusion, we recommend a continuing reform of Swedish instruction by means of increasing authentic encounters in Swedish, both live and on-line.

Keywords: Swedish as the second national language, instructional practices, learning outcomes, national evaluations of learning outcomes, assessment 


\section{Finländska svensklärares undervisningspraktiker och deras samband med elevers inlärningsresultat}

I den här artikeln fokuserar vi på faktorer som har att göra med undervisning och inlärning av svenska i finskspråkiga skolor i Finland. Vår utgångspunkt är att lärares undervisningspraktiker (arbetssätt) har betydelse för inlärningsresultaten, dvs. hur bra eleverna når de inlärningsmål som definieras i läroplanen. Inlärningsresultaten granskas genom de resultat som eleverna har fătt i den nationella utvärderingen 2013. De vid tidpunkten för undersökningen gällande läroplansgrunderna (Utbildningsstyrelsen, 2004) omfattade delområdena språkkunskaper, strategier och kulturkunskaper. Syftet med den aktuella studien är att beskriva och analysera lärares självrapporterade undervisningspraktiker och undervisningsrelaterade uppfattningar samt att analysera sambanden mellan dessa och elevers språkkunskaper i svenska. De olika bedömningssätt som lärarna använder ses som en viktig del av deras undervisningspraktiker.

Vår undersökning baserar sig på materialet från den nationella utvärderingen av inlärningsresultaten i moderna språk våren 2013. Utvärderingen var en del av det nationella utvärderingssystemet som bygger på lagen om den grundläggande utbildningen. Syftet med utvärderingen var att beskriva och analysera i vilken grad de inlärningsmål som ställs i de nationella läroplansgrunderna hade uppnåtts i svenska som det andra inhemska språket. I utvärderingen strävade man också efter att reda ut vilka faktorer som förklarar inlärningsresultaten (Hildén \& Rautopuro, 2014a). Utvärderingarna är sampelbaserade och omfattar ungefär fem procent av åldersklassen. Motsvarande utvärderingar har gjorts också tidigare i de vanligaste språkämnena sedan 1970-talet. Den långa lärokursen i svenska som det andra inhemska språket undersöktes förra gången år 2001 (Tuokko, 2002) och den obligatoriska medellånga lärokursen år 2008 (Tuokko, 2009). Resultaten från nationella utvärderingar används nationellt och lokalt i informativt syfte, t.ex. för att undersöka jämlikheten mellan flickor och pojkar och olika geografiska områden samt för att genom spridning av den inhämtade kunskapen förbättra inlärningsmiljöer och lärande.

I utvärderingen 2013 deltog sammanlagt 1679 randomiserade 9-klassister och 98 lärare från 73 finskspråkiga skolor. Eleverna hade läst den långa lärokursen i svenska som det andra inhemska språket. Den nivåskala för språkkunskaper som användes är en i Finland utarbetad tillämpning av de skalor som ingår i den allmäneuropeiska referensramen (CEFR, 2001; 
Utbildningsstyrelsen, 2004, s. 278; Hildén \& Takala, 2007). För betyget 8 (goda kunskaper) utav 10 som högsta betyg, är den eftersträvade färdighetsnivån enligt läroplansgrunderna den europeiska A2.2 i hör- och läsförståelse och A2.1 i tal och skrift. Dessa innebär i praktiken att eleven kan klara sig i enkla vardagliga situationer med ett begränsat men någorlunda funktionellt ordförråd. På denna nivå finns det tydliga brister i språkriktigheten även gällande basstrukturerna, men det viktigaste budskapet når fram. I läroplansgrunderna ställs upp också andra än språkliga mål, t.ex. kulturell kompetens och inlärningsstrategier, men dessa berörs inte i den här studien. Eftersom vi är intresserade av lärares undervisningspraktiker och undervisningsrelaterade uppfattningar samt deras samband med elevers språkkunskaper i svenska, ställer vi följande forskningsfrågor:

1. Vilka undervisningspraktiker och vilka uppfattningar om de faktorer som påverkar hur bra inlärningsmålen i läroplanen nås finns det hos lärare i svenskans långa lärokurs?

2. Vilka samband finns det mellan lärares undervisningspraktiker och uppfattningar samt elevers kunskaper i svenska med hänsyn till kön och föräldrarnas utbildningsbakgrund?

3. Vilka praktiker använder lärarna vid bedömning av elevers kunskaper?

Undervisning som målinriktad verksamhet omfattar hela den didaktiska processen från planering till bedömning. Här använder vi termen bedömning i vid betydelse för att beteckna alla typer av utvärdering och evaluering av elevers inlärning, inte enbart betygsättning.

\section{Lärarens undervisningspraktiker och deras inverkan på elevers inlärning}

Läraren spelar en avgörande roll för elevers inlärning i och med att hon eller han genom val av arbetssätt påverkar interaktionsmönstren i undervisningssituationen och även utanför den (Ellis \& Shintani, 2014, ss. 194-248; Hattie, 2012). Detta kommer fram i samtliga aktuella inlärnings- och undervisningsteorier, inte minst i den sociokulturella teorin; ur det sociokulturella perspektivet ses undervisningen som ett led i en process där omgivningens sociala praktiker internaliseras genom språkanvändning (Vygotsky, 1982; Lantolf \& Thorne, 2006) med hjälp av pedagogiskt välplanerade och meningsfulla uppgifter (Long, 2015).

Dessutom kan läraren påverka skoltrivseln, vilket också främjar inlärningen. Skoltrivseln har bland annat att göra med hur eleverna upplever läraren och undervisningsmetoderna; dessutom har attityder till språket och elevens egen studieframgång betydelse (Undervisningsoch kulturministeriet, 2012, ss. 41-42). I WHO:s utredningar har det kommit fram att Finland 
klarar sig relativt dåligt när det gäller skoltrivseln (Kämppi et al., 2012, s. 27). Enligt SalmelaAro och hennes forskargrupp är ett stort antal finländska ungdomar trötta och ointresserade av skolan (Salmela-Aro, 2017; Salmela-Aro \& Tuominen-Soini, 2013). Genom sina arbetssätt och val av uppgifter har läraren en möjlighet att påverka elevers erfarenheter och upplevelser av inlärningskontexten (Ellis \& Shintani, 2014, ss. 303-309, 313-314).

Enligt principen för konstruktiv samordning (el. konstruktiv länkning; constructive alignment; Biggs \& Tang, 2011) är studentens egen aktivitet som strävar efter en djupare förståelse en förutsättning för inlärningen. För att hela inlärningsprocessen ska fungera optimalt, ska inlärningsmålen, undervisningspraktikerna, inlärningsuppgifterna och bedömningen vara i linje med varandra och därmed stöda varandra. Således har undervisningspraktikerna och bedömningsmetoderna en central roll i hur inlärningsmålen kan nås.

\section{Kännetecken för kommunikativ språkundervisning}

Undervisningspraktiker är cykliska aktiviteter som omfattar planering, genomförande och bedömning av inlärningsprocessen i syfte att främja inlärningen (Hildén, 2009).

Modifikationer av den kommunikativa språkundervisningen understödda av pedagogiska uppgifter (som närmast motsvarar task-oriented eller task-supported language teaching i Longs (2015) terminologi) är erkända som den finländska språkundervisningens officiella rättesnöre sedan flera decennier. Kännetecken för denna kanon inbegriper en rad föreställningar och rekommendationer med varierande förankring i empirisk forskning. Eftersom dessa förmedlas och intränas genom språklärarutbildningarna över hela landet, har de visat sig vara styrande principer i undersökningar av språklärares arbetssätt och pedagogiska tänkande (Hildén et al., 2015; Harjanne, Reunamo \& Tella, 2015).

De allmänt erkända principerna omfattar bland annat följande punkter (sammanställda och modifierade från Ellis \& Shintani, 2014; Hildén, 2009; Utbildningsstyrelsen, 2004). De uppgifter (tasks) som används i undervisningen ska erbjuda elever möjligheter till samverkan, ömsesidig respons och adekvat stöd från läraren och kamraterna. De ska förankras i vardagslivet och i för elever relevanta kommunikationssituationer utanför skolan. Det ses som viktigt att uppgifterna fokuserar på sådant som har relevans för elever utöver inlärningen av ett grammatiskt fenomen och att elever får rikliga tillfällen att producera ny kunskap och uttrycka egna åsikter. De ska ha möjligheter att mångsidigt utnyttja sina kognitiva och språkliga resurser i samband med inlärningsaktiviteterna. När det gäller grammatiken, ska den 
beaktas och instrueras i lämplig utsträckning för att stöda kommunikationen, inte som ett självändamål; överlag ska betydelse föredras före form. Undervisningen ska stöda elevers identitetsutveckling och beakta deras individuella behov och kunskapsprofiler. Därtill ska undervisningen främja elevers mångkulturella kompetens och uppmuntra dem till möten med representanter för andra kulturer på målspråket, en aspekt som är allt viktigare i dagens globaliserade värld. Nuförtiden är språklig mångfald dessutom en faktor som ska beaktas i undervisningen. Med dessa principer (bl.a. Utbildningsstyrelsen, 2004) som utgångspunkt formulerades de konkreta frågorna i lärarenkäten.

Det finns undersökningar som visar att varierande arbetssätt bidrar till en effektivare inlärning av språkligt stoff (Pica, 2005; Ellis, 2009; Livingstone, 2011). Man kan till och med säga att ett mångsidigt språkbruk förutsätter varierande arbetssätt: varierande undervisningsmetoder är nödvändiga när man övar muntlig och skriftlig färdighet men också när man övar olika språkanvändningssituationer, uttal och så vidare. Därtill är det till nytta för eleverna att man utvecklar deras studiefärdigheter för att öka deras autonomi (Chamot, 2005; Benson, 2007) och att man erbjuder dem välriktat stöd (scaffolding) under undervisningens gång (Samuda \& Bygate, 2008). Under den senaste tiden har användning av lärmiljöer utanför skolan i form av sociala medier och informationsteknologiska tillämpningar beaktats i allt högre grad (t.ex. Marczak, 2013; Tudini, 2015; Wrigglesworth \& Harvor, 2017) inom språkundervisningen. I de vid tiden för materialinsamlingen gällande läroplansgrunderna för den grundläggande utbildningen (Utbildningsstyrelsen, 2004) betonades kommunikation och samverkan; därmed sågs inlärningen som ett socialt betingat fenomen. Det säger sig självt att det kommunikativa idealet $\mathrm{i}$ undervisningen bör få återklang i bedömningen. Trots detta verkar bedömningsmetoderna i språkundervisningen i Finland vara tämligen ensidiga med betoning på skriftliga färdigheter (Hildén \& Rautopuro, 2014a, 2014b; Härmälä, Huhtanen \& Puukko, 2014, s. 120; Hildén et al., 2015, ss. 160-170, 181; Hildén \& Rautopuro, 2014b, ss. 104, 111-115, 203209; Hildén \& Rautopuro, 2014c, ss. 128-130, 237). Därför skulle det vara viktigt att öka användningen av olika formativa bedömningssätt (Lantolf \& Thorne, 2006; McNamara \& Roever, 2006) samt att lära eleverna att evaluera sig själva och styra sin egen inlärning. Liknande målsättningar ingår också i de kompetenser som av OECD uppgetts vara centrala för 2000-talet. Det har konstaterats att bedömningspraktikerna styr inlärningen kraftigt (backwash effect of assessment; Biggs \& Tang, 2011, s. 197). Det som evalueras visar vad som uppskattas och vad man därför bör betona i undervisning och inlärning (Boud, 2000, s. 160). Ensidig bedömning leder lätt till att man studerar ensidigt. 


\section{Tidigare forskning om lärarens pedagogiska tänkande och agerande samt deras inverkan på elevers inlärningsresultat}

Vetenskapliga studier kring lärarkognition och lärares uppfattningar om sin profession har ökat i antal sedan millennieskiftet; enligt de flesta definitionerna omfattar lärarkognitionen både känslomässiga och kunskapsbaserade beståndsdelar som båda formas av handling och beteende genom reflektion (Barcelos \& Kalaja, red., 2011; Borg, 2006). Det är även värt att beakta att de olika komponenterna i lärarkognitionen inte fungerar i logiskt samspel enligt kausala mönster: lärare kan agera annorlunda än vad de uppger i intervjuer eller enkäter, vilket beror på arbetets situationsbundna natur som förutsätter snabba beslut i ett mångdimensionerat socialt spelrum (Sanchez \& Borg, 2014). Som en syntes av olika definitioner i tidigare studier (t.ex. Barcelos \& Kalaja, red., 2011) definierar vi uppfattningar som uttalade ställningstaganden angående värderingar, åsikter och erfarenheter kring språkundervisningen i allmänhet och det egna arbetet i synnerhet.

Det finns forskning om hur lärares uppfattningar och praktiker gällande undervisning och bedömning inverkar på det dagliga skolarbetet och därigenom även på elevers inlärning och syn på sitt kunnande (se t.ex. Barnes, Fives \& Dacey, 2015, ss. 296-297; Brown, 2008, ss. $2-$ 3, 2011, s. 2). Undervisningspraktikerna påverkar elever på olika sätt och i olika omfattning. Pojkar och flickor reagerar något olika på samma anvisningar och anammar olika innehåll i olika takt. Enligt en evaluering av inlärningsresultaten i engelska språket (Härmälä et al., 2014) uppgav flickor mer sällan än pojkar att läraren uppmuntrade dem att använda målspråket utanför skolan och att läraren gav dem respons på deras prestationer, medan flickor ansåg att de gör muntliga uppgifter oftare än pojkar. Vad språkfärdighetsresultaten beträffar var pojkars kunskaper bättre i samtliga delområden och sambandet mellan undervisningspraktikerna och resultaten tedde sig tämligen svagt överlag med undantag av språkbruk på fritiden som hade ett entydigt samband med samtliga delområden av engelska (Härmälä et al., 2014).

I de övriga främmande språken, tyska, franska och ryska (Utbildningsstyrelsen, 2014b), var skolans och undervisningens roll mer betydande i förhållande till inlärningsresultaten för båda könen. Skillnaderna som upptäcktes vittnade om flickors försprång. I allmänhet visade evalueringarna högst måttliga samband mellan enstaka praktiker och uppnådda färdighetsnivåer, bortsett från den avgörande roll som kan tillskrivas hemuppgifter: 
regelbundet arbete med hemuppgifter var genomgående förknippat med bättre inlärningsresultat, men eleverna var inte speciellt vana vid självstyre i något av de evaluerade språken. De få samband som förekom vittnar om en positiv inverkan av autonomifrämjande arbetssätt på färdighetsutvecklingen.

Ytterligare kännetecknas lärareffekten av variation med hänsyn till sociologiskt betingade variabler som familjens socioekonomiska ställning, föräldrarnas utbildningsnivå, skolans storlek och undervisningsspråk samt bostadsort. Den riktgivande studien inom den sociologiska tolkningsramen som utgavs av Colemans grupp (Coleman et al., 1966) har bevarat sin relevans genom tiderna. Även det centrala resultatet står fast: barn från högre socioekonomiska befolkningsgrupper klarar sig bäst i skolan (Sirin, 2005; Bradley \& Corwyn, 2002; Caro, McDonald \& Willms, 2009).

I den finländska undersökningen av inlärningsresultaten i språk (Utbildningsstyrelsen, 2014b) är det dock igen fråga om statistiskt anspråkslösa samband och skillnader vad enstaka praktiker beträffar. I genomsnitt tog barn till välutbildade föräldrar del av lärarens råd och anvisningar oftare och ivrigare än elever från hem med lågutbildade vuxna. Vissa regionala skillnader i mångfalden av praktiker upptäcktes till fördel av städer och tätt bebyggda kommuner, där även resultaten i genomsnitt var högre än i landsortsliknande kommuner. I regional jämförelse klarade elever i södra och västra Finland i allmänhet bättre av utvärderingsuppgifterna än elever i östra och norra delar av landet (Utbildningsstyrelsen, 2014b). I vår egen undersökning vill vi gå djupare in på liknande frågeställningar och fokuserar på svenska som det andra inhemska språket.

\section{Svenskan i den finländska grundskolan}

I och med att grundskolesystemet stegvis genomfördes i Finland på 1970-talet (1972-1977) blev svenskan ett obligatoriskt skolämne; beslutet om detta fattades redan 1968. Under de senaste åren har svenskans ställning i skolsystemet blivit ett (tidvis hett) diskussionsämne i medierna (se också Juurakko-Paavola \& Palviainen, red., 2011), fast finska och svenska enligt Finlands grundlag, § 17, är landets två nationalspråk (Finlex, 11.6.1999/731). Andelen svenskspråkiga av Finlands befolkning är ca 5,3 \%, dvs. ungefär 290000 personer (Statistikcentralen, 2017a).

De flesta finskspråkiga skoleleverna väljer engelska som A1-språk (lång lärokurs), vilket innebär att undervisningen i språket börjar senast i årskurs 3 (fr.o.m. början av 2020 från 
årskurs 1) i grundskolan. Svenska kan i så fall väljas som frivilligt A2-språk och då börjar undervisningen senast i årskurs 5. De allra flesta väljer dock svenska som ett så kallat B1språk (medellång lärokurs) som ända till läsåret 2015-2016 inleddes i årskurs 7 (Statistikcentralen, 2017b). Från och med hösten 2016 är svenskundervisningen tidigarelagd så att den börjar redan i årskurs 6. När det gäller antalet undervisningstimmar är skillnaden mellan A1-språk och B1-språk mycket stor; antalet timmar är 608 respektive 228 (gäller situationen ända till början av 2020). Det knappa antalet undervisningstimmar kan framstå som ett problem med tanke på inlärningsresultaten. Jämfört med 1970-talet har antalet timmar i B1-språk halverats. (För mer information se Undervisnings- och kulturministeriet, 2012, ss. 29, 39; Rossi et al., 2017.)

Det minskade timantalet och en rad andra faktorer återspeglar sig i försämrade inlärningsresultat för den medellånga B1-lärokursens del mer än under tidigare årtionden. Enligt en undersökning från år 2008 var kunskaperna i B1-svenska endast nöjaktiga i slutet av grundskolan. Det som var speciellt oroande var den låga kunskapsnivån i språkproduktionen (Tuokko, 2009). Pojkars kunskaper i språket var dessutom betydligt sämre än flickors (Takala, 2012, s. 3; Undervisnings- och kulturministeriet, 2012, s. 31). När det gäller den långa lärokursen i svenska är situationen mycket ljusare. Enligt den nationella utvärderingen av inlärningsresultaten från år 2013 (Hildén \& Rautopuro, 2014a) är niondeklassisternas språkkunskaper goda eller utmärkta. I hörförståelse nåddes målet utmärkt, i läsförståelse bra (då den eftersträvade färdighetsnivån för goda kunskaper var A2.2 enligt CEFR, 2001). I tal nåddes målet utmärkt, i skrift bra (då den eftersträvade färdighetsnivån för goda kunskaper var A2.1 enligt CEFR, 2001).

Det talas ett stort antal olika språk i Finland, men de finländska ungdomarnas språkkunskaper blir allt snävare. Bland annat med tanke på näringslivets behov är ett brett spektrum av olika språk nödvändigt; samtidigt är betydelsen av goda kunskaper i det andra inhemska språket svenska fortfarande central. (Se Undervisnings- och kulturministeriet, 2017a, 2017b.)

\section{Genomförande, material och metod}

En central del av vårt material utgörs av lärarnas svar på den så kallade lärarenkäten som användes i den nationella utvärderingen år 2013 för att få fram lärarnas uppfattningar om sina arbetssätt i såväl numerisk som verbal form. Lärarenkäten bestod av åtta delar som står för vissa centrala komponenter i lärarkognitionen (t.ex. Borg, 2006; Gitomer \& Zisk, 2015). I 
enkäten kartlades bakgrund, undervisningspraktiker, mål och bedömning, utveckling i yrket, uppfattningar om skolan, läroplanen och språkundervisningen, respons på utvärderingsuppgifterna samt önskemål till dem som höll på med utarbetning av de nya läroplansgrunderna. I den här undersökningen använder vi delarna Undervisningspraktiker, Mål och bedömning samt Önskemål till läroplansutvecklare. Frågorna i enkäten ställdes i enlighet med tillämpningen av den sociokulturella teorin och principerna för den kommunikativa språkundervisningen (se avsnittet Kännetecken för kommunikativ språkundervisning).

Lärarenkäten besvarades av 98 svensklärare från 73 olika finska skolor. Av lärarna hade 96 finska som modersmål, medan 2 var svenskspråkiga. Majoriteten (92 \%) av lärarna var kvinnor. Den yngsta var 27 år, den äldsta 63 år. Närmare $95 \%$ av dem var behöriga språklärare. Ca $57 \%$ hade avlagt fördjupade studier och ca $38 \%$ ämnesstudier i undervisningsämnet. Över hälften hade jobbat i grundskolan över 10 år. 35,7 \% av lärarna undervisade i svenska och engelska, 27,6 \% i svenska, 14,3\% i svenska och tyska, 8,2 \% i svenska, engelska och tyska. $4 \%$ undervisade inte alls i svenska vid tiden för utvärderingen. Den tid som lärarna hade vistats i ett område där det talas svenska varierade från över 2 år $(42,7 \%)$ till ingen vistelse alls $(8,3 \%)$. Alla förutom två lärare bedömde sina svenskkunskaper på alla delområden som minst B2.1. (För närmare information se Hildén \& Rautopuro, 2014a.)

I den nationella utvärderingen (Hildén \& Rautopuro, 2014a) testades elevers språkfärdighet med uppgifter som hade konstruerats i enlighet med den kommunikativa språkundervisningens etablerade principer. Dessa innebär att den språkliga uppgiften sätts i en kontext som liknar språkbruk i vardagssituationer och omfattar såväl tal som skrift. Uppgifterna bestod av en uppsättning hör- och läsförståelseuppgifter samt två skrivuppgifter och ett partest i tal. De muntliga uppgifterna omfattade en monolog, två vardagssituationer med finska anvisningar samt en problembaserad diskussionsuppgift. I utvärderingen deltog 1679 elever till 98 lärare från 73 finska skolor. Av eleverna var 59 \% flickor, 41 \% pojkar. De muntliga uppgifterna gjordes av 859 elever (Hildén \& Rautopuro, 2014a). I denna artikel fokuserar vi på lärarenkäten och elevers språkfärdighetstest.

För att kunna komma åt eventuella skillnader i inlärningsresultaten jämfördes de statistiska sifferkoderna av lärarnas svar med inlärningsresultaten av deras elever. Lärarsvaren faktoriserades och summavariablerna av de olika faktorerna användes som nya variabler i 
fortsatta analyser. Elevprestationerna i att höra, tala, läsa och skriva svenska beskrevs med en nationellt tillämpad skala av det europeiska nivåsystemet.

Materialet har analyserats både kvantitativt och kvalitativt. Den kvantitativa analysen av svaren till lärarenkäten bestod av en grundläggande kalkylering av frekvenser och medelvärden för enstaka variabler som karakteriserar lärarnas arbetssätt och uppfattningar. Sambanden mellan variablerna granskades också med hjälp av korrelationer. Därtill bearbetades materialet med explorativ faktoranalys (Metsämuuronen, 2006) som bidrog till att definiera de väsentliga dimensionerna i svensklärarnas undervisningspraktiker och förhållningssätt. Poängen för variablerna inom varje faktor sammanställdes till variabelblock som i sin tur korrelerades med helhetspoängen för varje språklig delfärdighet för att fastställa deras inverkan på inlärningsresultaten.

I den kvalitativa analysen gick vi igenom svaren på alla de öppna frågorna i lärarenkäten och använde kvalitativ innehållsanalys (Miles \& Huberman, 1994; Schreier, 2014) för att ta reda på hurdana uppfattningar lärarna hade om faktorer som påverkar hur bra eleverna når inlärningsmålen. De fyra öppna frågorna i lärarenkäten var följande: Vilka faktorer främjar eller försvårar uppnåendet av inlärningsmålen i det språk som du undervisar i? (fråga 21); Din respons gällande utförandet och evalueringsuppgifterna? (fråga 47); Hurdant stöd skulle du önska till undervisning av det evaluerade språket? (fråga 48); Berätta om dina åsikter och önskemål för att stödja arbetet i de grupper av utvecklare och administratörer som bereder grunderna för läroplanen (fråga 49). Den första öppna frågan hade direkt att göra med vår första forskningsfråga, dvs. vilka uppfattningar och undervisningspraktiker som finns hos lärare i svenskans långa lärokurs. Lärarna hade dock beskrivit sina uppfattningar och sina arbetssätt också i samband med de andra öppna frågorna. Därför gick vi igenom alla svaren på de öppna frågorna och tog med det som hade med forskningsfrågan att göra. För att analysen skulle vara så pålitlig som möjligt analyserade vi först materialet var för sig och sedan jämförde och diskuterade vi våra tolkningar i flera omgångar. Som ett resultat av denna process hittade vi sex stycken teman som vi beskriver närmare i resultatdelen.

En potentiell felkälla vid undersökning av lärarkognitionen är motstridigheten mellan det gjorda och det sagda som i enkätundersökningar dels kan härstamma från respondenters benägenhet att ge svar som anses socialt acceptabla, dels från rena oförmågan att uppfatta skillnaden mellan ideal och verklighet i det egna beteendet (Borg, 2006). Samma felkälla gör sig gällande i fråga om praktiker, men närmare sanningen kommer man inte med surveyteknik. Undersökningen är dock sampelbaserad och täcker alla kommuner och regioner 
i Finland (Nationella centret för utbildningsutvärdering, 2014). Det är ganska sällan man har möjlighet att använda dessa typer av omfattande material.

\section{Resultat}

I detta avsnitt redogör vi för våra analysresultat. Först går vi igenom materialet ur ett kvantitativt perspektiv för att besvara forskningsfråga nr 1 (Vilka undervisningspraktiker och vilka uppfattningar om de faktorer som påverkar hur bra inlärningsmålen i läroplanen nås finns det hos lärare i svenskans långa lärokurs?). Därefter genomförs en statistisk jämförelse för att belysa problematiken i anknytning till forskningsfråga nr 2 (Vilka samband finns det mellan lärares undervisningspraktiker och uppfattningar samt elevers kunskaper i svenska med hänsyn till kön och föräldrarnas utbildningsbakgrund?) och fråga nr 3 (Vilka praktiker använder lärarna vid bedömning av elevers kunskaper?). I den kvalitativa delen fördjupar vi resultaten från den kvantitativa analysen genom en tematisk innehållsanalys av lärarnas svar på de öppna frågorna i enkäten gällande deras uppfattningar.

Undervisningspraktiker och undervisningsrelaterade uppfattningar hos lärare i svenskans långa lärokurs: kvantitativ genomgång

\section{Lärarnas undervisningspraktiker}

Lärarenkäten innehöll ett stort frågebatteri (113 frågor) som gav mycket information. Denna information komprimerades med hjälp av faktoranalys. Faktoranalysen resulterade i sju dimensioner som anges i tabell 1 .

Tabell 1: Dimensioner av lärarpraktiker och de mest frekventa kommunikativa arbetssätten som lärarna anger sig använda i sin undervisning. Siffrorna inom parentes är medelvärden för dimensionen/kärnpåståendet på skalan 1-5. (Hildén \& Rautopuro, 2014a, s. 103)

Muntlig övning (5 st. påståenden) $(2,7)$

Eleverna gör muntliga parövningar från läroboken $(4,3)$

Moderna arbetssätt (4 st. påståenden) $(1,3)$ 
t.ex. inlärningsdagbok, videoinspelning av diskussioner, användning av språkportfölj

Autentiskt språkbruk (6 st. påståenden) $(2,1)$

Vi använder internet för att söka information $(2,9)$

Mångsidiga undervisningsmetoder (5 st. påståenden) $(3,6)$

Läraren ger skriftliga uppgifter som hemuppgift $(4,4)$

Användning av media (5 st. påståenden) (2,5)

Vi tittar och lyssnar på filmer, låtar etc. på målspråket $(3,4)$

Uppmuntrande respons (4 st. påståenden) $(3,3)$

Läraren lyssnar och ger respons när eleverna diskuterar $(3,1)$

Självstyrning (6 st. påståenden) $(2,5)$

Läraren diskuterar elevernas studieframsteg med dem $(4,3)$

När vi jämförde korrelationen mellan dimensionerna och språkfärdigheten, visade sig Muntlig övning vara den mest relevanta dimensionen (förklarade i genomsnitt 4,2\% av delfärdigheterna: tala, skriva, läsa och höra), följd av dimensionerna Moderna arbetssätt (förklaringsprocent 1,2) och Autentiskt språkbruk (förklaringsprocent 1,5).

När lärarens arbetssätt granskades tvådimensionellt med hänsyn till elevers delfärdighet och kön, framgick något olika mönster för flickors och pojkars del (se tabell 2). Av alla undervisningspraktiker bidrog Muntlig övning mest till pojkars receptiva färdigheter (att höra och läsa), medan effekten var klart svagare bland flickor. Tendensen upprepas för varje dimension på ett sätt som tyder på att pojkars språkliga färdigheter är mer beroende av undervisningen än flickors (Hildén \& Rautopuro, 2014a). Flickorna blir mognare i ett tidigare skede än pojkarna, vilket kan ha betydelse också för deras språkinlärning (You, Dörnyei \& Csizer, 2016).

Tabell 2: Korrelationerna mellan lärarens arbetssätt och elevers språkliga delfärdigheter (höroch läsförståelse) enligt kön.

\begin{tabular}{|l|l|l|l|l|}
\hline & Pojkar/Höra & Flickor/Höra & Pojkar/Läsa & Flickor/Läsa \\
\hline Autentiskt språkbruk & $0.20 * *(4,0 \%)$ & $0.07(0,5 \%)$ & $0.22^{* *}(5,0 \%)$ & $0.07(0,5 \%)$ \\
\hline $\begin{array}{l}\text { Mångsidiga } \\
\text { undervisningsmetoder }\end{array}$ & $0.10^{* *}(1,0 \%)$ & $0.05(0,2 \%)$ & $0.10(1,0 \%)$ & $0.04(0,1 \%)$ \\
\hline
\end{tabular}




\begin{tabular}{|l|l|l|l|l|}
\hline Användning av media & 0.04 & -0.004 & 0.05 & 0.01 \\
\hline $\begin{array}{l}\text { Uppmuntrande } \\
\text { respons }\end{array}$ & 0.02 & 0.01 & 0.06 & 0.05 \\
\hline Självstyrning & $0.11^{* *}(1,0 \%)$ & 0.01 & $0.16^{* *}(3,0 \%)$ & 0.03 \\
\hline Moderna arbetssätt & $0.24 * *(5,8 \%)$ & $0.15^{* *}(2,3 \%)$ & $0.20^{* *}(4,0 \%)$ & $0.14^{* *}(2 \%)$ \\
\hline Muntlig övning & $0.24^{* *}(6,0 \%)$ & $0.17^{* *}(3,0 \%)$ & $0.24^{* *}(6,0 \%)$ & $0.17^{* *}(3 \%)$ \\
\hline
\end{tabular}

**Två stjärnor innebär att korrelationen är statistiskt signifikant $(\mathrm{p}<0,05)$.

Tabell 2 visar korrelationskoefficienten samt förklaringskraften som procent. Överlag visar den statistiska analysen att korrelationerna är tämligen svaga. Fenomenet är komplext och påverkas av hela kontexten, inte enbart av enstaka arbetssätt. När det gäller produktiva delfärdigheter (att tala och skriva) förblir sambanden med undervisningspraktiker ännu anspråkslösare än i fråga om hör- och läsförståelse, men fortfarande påverkas pojkar mer av undervisningen än flickor.

En annan väletablerad variabel i pedagogiska undersökningar och utredningar är föräldrarnas utbildning (se också Thomas \& Collier, 1997; OECD, 2015), denna gång operationaliserad i elevenkäten genom frågan Har dina föräldrar tagit studentexamen? (sammanlagt innehöll elevenkäten 55 frågor). I stort sett alla tidigare undersökningar (se också Tuokko, 2002, 2009) som gjorts om grundskoleelevers kunskaper i moderna samhällen pekar åt samma håll i och med att ju högre föräldrarnas utbildningsnivå är desto bättre resultat når barnen (Dubow, Boxer \& Huesmann, 2009; Davis-Kean, 2005). Evalueringen av inlärningsresultaten i språk 2013 utgjorde inget undantag: de elever vars båda föräldrar hade tagit studentexamen uppnådde inlärningsmålen bäst, på andra plats kom de vars ena förälder var student och lägst förblev resultaten hos barn till dem som inte tagit studentexamen.

De tre dimensionerna Muntlig övning, Moderna arbetssätt och Autentiskt språkbruk återspeglade sig olika i språkfärdigheten hos elever från olika föräldrabakgrund. Enligt resultaten verkar undervisningspraktikerna ha mest inverkan på sådana elevers språkfärdighet vars båda föräldrar avlagt studentexamen. Mönstret gäller både receptiva och produktiva delfärdigheter. Muntlig övning är den gynnsammaste dimensionen för de flesta eleverna, bortsett från läsförståelseförmågan hos barn till dem som inte tagit studentexamen. Moderna aktiviteter och Autentiskt språkbruk stödde främst elever med minst en student till förälder. Dessa elever är eventuellt mer socialiserade i de praktiker som skolan representerar (Coleman 
et al., 1966; Kärkkäinen, 2004). Resultaten är intressanta om än smått oroande med tanke på jämlikheten: når skolundervisningen fortfarande bäst de barn som har högutbildade föräldrar? Här kan man lyfta fram betydelsen av det så kallade sociala arvet. Högt utbildade föräldrar har ofta mer positiva förväntningar på sina barns skolframgång; barnen får kanske från början en sådan modell att det lönar sig att studera och reflektera på olika saker. Dessutom har dessa barn eventuellt mer utvecklade studiestrategier. Man vet från tidigare undersökningar från universitetsvärlden (t.ex. Virtanen, Postareff \& Hailikari, 2015; Struyven, Dochy \& Janssens, 2005) att de studenter som har bristfälliga studiestrategier och som inte litar på sin egen förmåga föredrar så kallade traditionella bedömningsmetoder, medan de som har utvecklade studiestrategier är mer positivt inställda till nya, alternativa metoder. Det är möjligt att detta också gäller för olika inlärningsmetoder på alla utbildningsnivåer.

Gällande enstaka arbetssätt angav lärarna att de talar svenska på lektionerna mycket ofta (medelvärde 4,1 på skalan 1-5). Lärarens användning av målspråket vid tilltal av hela klassen hade statistiskt signifikanta samband med samtliga delfärdigheter, varav det starkaste med tal $(r=0,20 ; p<0,01)$ och det svagaste med skrivfärdighet $(r=0,08 ; p<0,05)$. Båda sambanden är dock mycket svaga i praktiken. Lärarens bruk av målspråket hade en positiv inverkan på elevers tal- och skrivfärdighet hos både flickor och pojkar. Likadana rön gav också den europeiska kartläggningen av språkkunskaper (European Commission, 2012, s. 88) även om forskningsrönen i allmänhet är tämligen kontroversiella vad angår användningen av undervisningsspråk vs. målspråk under lektionerna (Ellis \& Shintani, 2014, s. 247).

\section{Lärarnas bedömningspraktiker}

Lärarnas bedömningspraktiker undersöktes genom en serie påståenden gällande frekvensen av vissa arbetssätt som kan anses höra till modern kommunikativ språkundervisning. Utöver dessa ombads lärarna att ange grunderna till sin betygsättning genom att välja och rangordna vikten av vissa beståndsdelar av kursbetyget. I frågeformuläret ingick en rad påståenden avsedda som indikatorer för moderna bedömningspraktiker (t.ex. Vi samlar europeisk språkportfölj, Vi ger respons till varandra, Vi bedömer våra egna kunskaper). Deras frekvenser förblev tämligen låga genomgående, och eventuella samband med inlärningsresultaten likaså obetydliga. Som ett enskilt riktgivande exempel kan nämnas att fri skriftlig produktion i prov visade sig vara gynnsam för både hörförståelsen och skrivförmågan. 
Lärarnas betygsättningsgrunder indelade sig i två block som rubricerades Arbetsinsats och attityd och Autentisk bedömning. I Arbetsinsats och attityd ingick hemuppgifter, aktiv arbetsinsats under lektionerna samt elevens attityd till studierna (även om attityd officiellt inte skulle beaktas i bedömningen). Autentisk bedömning omfattade muntliga prov, projektarbete, muntligt språkbruk på lektionerna och aktivt språkbruk utanför skolan. Komponenten Arbetsinsats och attityd fick högst frekvens (medelvärde 4,3 på skalan 1-5). Det verkar vara så att lärarna fortfarande tillämpar invanda traditionella metoder och att tröskeln att börja använda nya arbetssätt är relativt hög.

Vad lärarnas summativa bedömningspraktiker beträffar visade analysen att traditionella ordprov (64\%) och fri skriftlig produktion i samband med proven (62\%) var populärast (se Hildén \& Rautopuro, 2014a, ss. 104-105). De fem mest använda formativa och moderna bedömningssätten framgår av tabell 3 .

Det kan hända att det som lärarna tror att de gör inte alltid syns för eleverna. Lärarna har kanske en mer positiv uppfattning om sina arbetssätt. Det är också möjligt att eleverna inte alltid ser eller kan använda de möjligheter som läraren erbjuder (se van Lier, 1996, 2000). En delförklaring kan dessutom vara att eftersom en och samma lärare kan ha flera grupper, använder hon eller han vissa arbetssätt mer med en del grupper än med andra. Som det kom fram i Hildén och Rautopuros (2014a) rapport, ansåg eleverna till exempel att responsen från lärarna var betydligt sällsyntare än vad lärarna själva nämnde i sina svar (Hildén \& Rautopuro, 2014a, s. 129). Lärarna upplever att de ger respons hela tiden, medan eleverna upplever att de inte får respons av lärarna. Att lärare och deras elever inte är genomgående ense om frekvensen av olika praktiker är ett välkänt fenomen även i tidigare undersökningar (se t.ex. Huhta \& Tarnanen, 2009).

Tabell 3. De fem mest använda moderna bedömningspraktikerna enligt lärare (i omvänd ordning)

\begin{tabular}{|l|c|c|c|}
\hline På lektionerna i årskurserna 7-9... & $\begin{array}{c}\text { Aldrig } \\
\text { Bara sällan } \\
(\%)\end{array}$ & Ibland (\%) & $\begin{array}{c}\text { Ofta } \\
\text { Nästan alltid } \\
(\%)\end{array}$ \\
\hline $\begin{array}{l}\text { samlar vi material i en portfölj eller } \\
\text { skriver inlärningsdagbok }\end{array}$ & 94,9 & 1,0 & 4,1 \\
\hline
\end{tabular}




\begin{tabular}{|l|c|c|c|}
$\begin{array}{l}\text { ger eleverna varandra feedback på } \\
\text { kunskaperna i det språk som studeras } \\
\text { (t.ex. i en muntlig uppgift) }\end{array}$ & 62,2 & 32,7 & 5,1 \\
\hline $\begin{array}{l}\text { utvärderar eleverna sina egna kunskaper } \\
\text { (t.ex. genom att fundera på hur de } \\
\text { lyckades eller genom att föreslå ett betyg) }\end{array}$ & 36,7 & 41,8 & 21,4 \\
\hline $\begin{array}{l}\text { talar jag med eleven om hans eller hennes } \\
\text { framsteg }\end{array}$ & 16,3 & 53,1 & 30,6 \\
\hline $\begin{array}{l}\text { lyssnar jag och ger feedback då eleverna } \\
\text { har pardiskussioner på målspråket }\end{array}$ & 12,2 & 32,7 & 55,1 \\
\hline
\end{tabular}

I lärarenkäten kartlades respondenternas värderingar (som en del av deras uppfattningar) gällande undervisningens mål och innehåll med en femgradig skala som sträckte sig från 1 till 5. Forskningen kring lärarnas uppfattningar om bedömning har visat att uppfattningarna inte bara reflekterar redan existerande bedömningspraktiker utan dessutom har en inverkan på det dagliga arbetet, bedömningspraktikerna och därigenom också inlärningen (Barnes et al., 2015, ss. 296-297; Brown, 2008, ss. 2-3, 2011, s. 2).

Som mycket viktiga ansågs följande målsättningar (medelvärden inom parentes): behärskning av ordförrådet (4,7); muntlig interaktion (att tala och lyssna t.ex. i en diskussion) $(4,4)$; läsning $(4,3)$; studiefärdigheter $(4,3)$; att växa som människa $(4,1)$; att möta olikhet $(4,1)$; skrivande $(4,1)$ och att våga uttrycka sig $(4,0)$.

Här kan vi se att lärarna ser ett stort ordförråd som ytterst centralt. De ställer sig dessutom synnerligen positiva till muntlig interaktion och främjandet av elevers mod att uttrycka sig. Lärarnas värderingar återspeglar i hög grad även de allmänna målsättningarna i de dåvarande läroplansgrunderna (Utbildningsstyrelsen, 2004). En del av dessa framhävs ytterligare i de nya grunderna (Utbildningsstyrelsen, 2014a), till exempel att bemöta olikhet och att växa som människa. I de nya läroplansgrunderna betonar man dessutom elevers studiefärdigheter och deras mod att använda språket. Sammantaget kan dessa svar tolkas som en gynnsam utgångspunkt för fortsatt arbete i de nya läroplansgrundernas anda.

Uppfattningar hos lärare i svenskans långa lärokurs: kvalitativ genomgång 
I det följande redogör vi för lärarnas uppfattningar om vilka faktorer som gör det lättare och vilka som gör det svårare att nå inlärningsmålen i läroplanen. Den kvalitativa redogörelsen baserar sig på lärarnas svar på fyra öppna frågor i enkäten och tar upp några av de mest centrala temana i lärarnas svar. Genom en kvalitativ innehållsanalys (Miles \& Huberman, 1994; Schreier, 2014) har vi hittat flera faktorer som lärare lyfter fram i sina svar, antingen som positiva eller som negativa med tanke på inlärningen. Dessa faktorer har att göra med undervisningsmetoder och läromaterial, lärmiljön i och utanför skolan, praktiska undervisningsarrangemang, elevers motivation och attityder samt lärares färdigheter och behov av fortbildning. Vissa av temana har direkt att göra med läraren och lärarens agerande, medan andra har att göra med faktorer som läraren inte kan påverka men som ändå åtminstone i viss mån - kan beaktas i undervisningen.

Undervisningsmetoder och läromaterial. Lärare önskar mer betoning på kommunikativa och vardagsnära språkkunskaper. Många lärare påpekar att muntliga kunskaper är viktiga och att man behöver tillräckligt mycket tid för att kunna satsa på det muntliga. I några av svaren kan man se att språkinlärning och trivsel ses som varandras motsatser. En lärare påpekar att motiveringen av elever blir lidande "då man inte hinner göra roliga saker" på lektionerna; det egentliga innehållet tar all tid. Också muntliga övningar kan ses som en "rolig sak" som man inte har tillräckligt mycket tid till. Här är lärarna kanske inte medvetna om att muntliga övningar främjar språkinlärningen överlag (se Hildén \& Rautopuro, 2014a, s. 143).

Samarbete med kolleger är ett sätt som kunde underlätta för lärarna att nå målen. Stödet från en resurslärare eller annan kollega skulle göra arbetsbördan lättare och ge möjlighet att variera lektionsinnehållet mera.

Föråldrade läroböcker nämns av lärare som ett problem, likaså bristen på lämpligt material på nätet. Det efterlyses nyare material som skulle vara närmare elevernas vardag och intressen. Välfungerande, autentiska och intressanta läromaterial bidrar till större motivation hos elever, vilket eventuellt leder till att inlärningsmålen kan nås bättre.

Lärmiljön i och utanför skolan. Undervisningsgrupperna är ofta stora och heterogena, vilket gör att de enskilda elevernas behov inte kan beaktas tillräckligt mycket och att få till bra arbetsro i klassen kan ta "största delen av lektionen". En lugn studiemiljö och en lämplig (dvs. tillräckligt liten) gruppstorlek bidrar till att målen kan uppnås.

Om svenskan syns och hörs i omgivningen är det lättare för elever att se svenskan som ett språk som man kan ha nytta av. Svenskspråkiga kamrater eller familjemedlemmar är 
naturligtvis till nytta. Dessutom är det en stor fördel om man lyckas utnyttja tvåspråkigheten i regionen. Många lärare skriver att svenskinlärningen lider av att svenskan inte syns i elevernas vardag. Det finns också lärare som konstaterar att de inte har lyckats utnyttja kommunens tvåspråkighet eller svenskans synlighet i omgivningen. Därmed ses tvåspråkigheten som en resurs som (åtminstone tills vidare) inte har kunnat utnyttjas i svenskundervisningen i tillräckligt hög grad.

Lärares färdigheter och behov av fortbildning. Lärarna tycks ha lite olika uppfattningar om hur bra den moderna tekniken stöder inlärningen. Det finns lärare som till exempel är oroliga över elevers användning av mobiler på lektionerna och lärare som ser datateknikens roll som överbetonad. Å andra sidan finns det också lärare som anser att användningen av datorer "motiverar eleverna otroligt mycket". Alla skolor har inte den utrustning som skulle behövas, och dåligt fungerande teknik upplevs som en utmaning. I vilket fall som helst är det viktigt att datorerna och programmen fungerar när de behövs och att lärarna kan använda dem. Enligt svaren kan det finnas brister i lärares tekniska kunnande.

Många av lärarna skulle gärna fortbilda sig om de hade en möjlighet till det. Bedömningen av muntliga färdigheter och användningen av den europeiska referensramen nämns som exempel på områden där tilläggsutbildning behövs. Många lärare tycks vara osäkra när det gäller bedömning: det upplevs som svårt att tillämpa CEFR-skalorna, speciellt gällande muntliga kunskaper. Dessutom önskas utbildning på och i svenska; vardagssvenska och kulturellt (nordiskt) innehåll skulle uppskattas. En lärare påpekar att tips gällande mångsidigare grammatikundervisning skulle vara välkomna.

Praktiska undervisningsarrangemang. En av de faktorer som lärare nämner som negativa med tanke på målsättningarna är att man inte har tillräckligt med tid för att kunna fördjupa innehållet på lektionerna utan är tvungen att "rusa från tema till tema". Därtill anses timresursen för svenskan vara alldeles för liten: en eller två veckotimmar räcker inte till, eller åtminstone hinner man inte med något "extra", som en av lärarna uttrycker det. Dessutom minskar olika typer av projekt, praoperioder, temadagar och semestrar på antalet undervisningstimmar. Som en lärare konstaterar, stöder en jäktig tidtabell inte utvecklandet av de muntliga kunskaperna; positiva attityder skulle likaså gynnas av en lugn och rofylld atmosfär.

Lärarna har lite olika åsikter om hur långa lektionerna borde vara. Vissa anser 75 minuters lektioner vara lämpliga och bra för inlärningen, medan andra ser dem som "inte de bästa 
möjliga" och till och med som icke-effektiva. Hur undervisningstimmarna placeras i schemat verkar ha relativt stor betydelse: förmiddagen ses som den fördelaktigaste tiden för svensklektioner. På eftermiddagen är det svårare för elever att koncentrera sig; många är trötta och orkar inte fokusera på lektionsinnehållet.

Elevers motivation och attityder. Olika typer av problem med arbetsron tas upp av många lärare. Likaså nämns elevers motivationsbrist, attitydproblem och orolighet men också passivitet som problem. Problemen uppges bli speciellt påtagliga då undervisningsgruppen är stor och orolig och det finns specialelever i gruppen; många elever har dessutom koncentrationssvårigheter och de pratar hellre med sina klasskamrater än jobbar med svenskan. Om timmarna dessutom hålls på eftermiddagen sägs situationen vara ännu besvärligare.

Bristande motivation och negativa attityder till svenskan hos elever ses som ett relativt stort problem som gör det svårare att nå målsättningarna. Ibland behövs det bara en högljudd elev som saknar motivation och är negativt inställd till språket för att hela gruppen ska påverkas. Det påpekas av lärare att den pågående diskussionen i samhället om (den obligatoriska) "tvångssvenskan" inte gör saken lättare.

Det finns dock forskning (t.ex. Lehti-Eklund \& Green-Vänttinen, 2011) som visar att också grundskoleelever kan vara mycket intresserade av svenskan och engagerade i sina studier. Det har visat sig att lärarens insats är central. Med varierande och kommunikativa arbetssätt kan läraren bidra till att eleverna trivs på lektionerna, vågar använda språket och vill utveckla sina språkkunskaper ytterligare.

\section{Sammandrag och diskussion}

I den här artikeln har vi undersökt finländska svensklärares arbetssätt och uppfattningar samt deras samband med elevers språkkunskaper. Gällande arbetssätten lyfte den kvantitativa analysen fram betydelsen av autentiskt språkbruk och muntliga övningar. Dessa har en positiv inverkan på alla delområden i språkfärdigheten. De muntliga övningarna visade sig vara viktiga speciellt för pojkars språkkunskaper. Det kan hända att pojkar ser de muntliga uppgifterna som mer motiverande, vilket gör att de bättre orkar jobba med dem. Det som den kvalitativa analysen ändå visade var att även om lärarna upplever de muntliga övningarna som värdefulla, ser de dem ibland som något "extra", något roligt som de inte alltid har tid till i vardagen. 
Resultaten visar att bedömningen av språkfärdigheten fortfarande är relativt traditionell (se också Hildén \& Rautopuro, 2014a). Ett viktigt och samtidigt oroande resultat var att lärarnas undervisningspraktiker mest gynnar sådana barn vars föräldrar har studentexamen (se också Dubow et al., 2009; Davis-Kean, 2005). Därför borde man fästa speciell uppmärksamhet på barn till dem som inte tagit studentexamen och fundera på olika sätt att stöda dem i undervisningen.

Beträffande lärares uppfattningar visade analysen att lärarna betonar och värdesätter mångsidiga metoder och övning av muntlig färdighet, men att de inte alltid har tid eller förmåga att använda dessa i praktiken. Således finns det en viss konflikt mellan det som lärarna ser som bra och värdefullt och det som de anser går att tillämpa i praktiken. Dessa resultat stämmer överens med tidigare undersökningar om lärarkognition (Borg, 2006).

Behärskningen av ordförrådet ses som viktig, men lärarna förstår också att muntliga kunskaper har en viktig roll som en del av språkfärdigheten och i bedömningen. Variationen i bedömningssätten borde ökas så att dessa på ett flexibelt sätt stöder elevers färdigheter till livslångt lärande. Lärarna ser det som svårt att använda svenskan i omgivningen som en resurs. Både de som hör svenska dagligen i sin närmiljö och de som inte alls hör svenska i vardagen, kommenterar hur svårt det är att göra den autentiska svenskan till en resurs i undervisningen. Några lärare uttrycker ett behov av nya och bättre läroböcker i den långa lärokursen.

I fråga om tillförlitligheten av undersökningen vill vi konstatera (i enlighet med t.ex. Borg, 2006) att det som lärarna nämner i sina svar och det som de gör i praktiken inte alltid sammanfaller. Dessutom kan det naturligtvis förekomma ett antal felkällor som är typiska för enkätundersökningar (bl.a. eventuella validitetsbrister i frågeställningar, brådska, missförstånd och strävan till socialt acceptabla svar). Trots eventuella brister i enkäten är det ändå frågan om ett representativt sampel som ger en helhetsbild av den finländska svenskundervisningen i slutet av förra läroplansperioden.

De principer som de nya läroplansgrunderna (Utbildningsstyrelsen, 2014a) bygger på syns redan i uppfattningarna men inte ännu helt i praktiken. För att principerna skulle konkretiseras i lärarnas dagliga arbete borde användningen av moderna arbetssätt ökas och autentiska möten på svenska främjas. Här vill vi påpeka att situationen delvis redan har blivit bättre efter 2013, då materialet för denna studie samlades in. Det finns allt fler svensklärare som har börjat använda mer studentcentrerade och kommunikativa arbetsmetoder i sin undervisning och som 
utnyttjar digitala medel på ett pedagogiskt motiverat sätt. Delvis är detta ett resultat av de nya läroplansgrunderna för den grundläggande utbildningen som togs i bruk 2014. Även om vissa positiva ändringar har skett, tar mer grundläggande förnyelser av undervisningspraktikerna alltid tid. Därför kan våra resultat från förra läroplansperioden fortfarande anses vara relevanta som vetenskapligt underlag för pedagogiska diskussioner och för planering av autentiska, mångsidiga och motiverande arbetssätt i klassrummen.

Om eleverna upplever uppgifterna som meningsfulla och tror på sin egen förmåga att lära sig, blir de mera engagerade, vilket kan främja inlärningen (Dörnyei \& Ushioda, red., 2011; Waninge, 2015, s. 204; Salmela-Aro, 2017, ss. 340-341). Genom ökad autenticitet i svenskstudierna kunde svenskans roll förstärkas som ett led i den ämnesintegrerade undervisningen som läroplansgrunderna lyfter fram samt i den allmänna språkpedagogiken. Det som sker i grundskolan utgör dessutom grunden för fortsatt inlärning, bland annat i gymnasiet och på längre sikt även i arbetslivet, helt i enlighet med principen för det livslånga lärandet.

I fortsatta studier skulle det vara intressant att forska i hur lärarna har börjat använda informationsteknologin i sin undervisning och huruvida användningen av digitala verktyg har påverkat t.ex. de typer av hemuppgifter som de ger till eleverna. Har uppgifterna blivit mångsidigare och mer autentiska? Och vad innebär autenticitet egentligen ur lärares och elevers perspektiv? Samtidigt kunde man reda ut hur eleverna har upplevt de nya arbetssätten.

\section{Referenser}

Barcelos, A. M. F. \& Kalaja, P. (red.) (2011). Beliefs about SLA revisited. System, 39 (3), $281-416$.

Barnes, N., Fives, H. \& Dacey, C. M. (2015). Teachers' beliefs about assessment. I H. Fives, \& M. Gregoire Gill (red.), International handbook of research on teacher beliefs (ss. 284-300). New York: Routledge.

Benson, P. (2007). Autonomy in language teaching and learning. Language Teaching, 40 (1), 21-40.

Biggs, J. \& Tang, C. (2011). Teaching for quality learning at university (4 uppl.). Maidenhead: Open University Press. 
Borg, S. (2006). The distinctive characteristics of foreign language teachers. Language Teaching Research, 10 (1), 3-31.

Boud, D. (2000). Sustainable assessment: Rethinking assessment for the learning society. Studies in Continuing Education, 22 (2), 151-167.

Bradley, R. H. \& Corwyn, R. F. (2002). Socioeconomic status and child development. Annual Review of Psychology, 53 (1), 371-399.

Brown, G. T. L. (2008). Conceptions of assessment: Understanding what assessment means to teachers and students. New York: Nova Science Publishers.

Brown, G. T. L. (2011). Teachers' conceptions of assessment: Comparing primary and secondary teachers in New Zealand. Assessment Matters, 3, 45-70.

Caro, D. H., McDonald, J. T. \& Willms, J. D. (2009). Socio-economic status and academic achievement trajectories from childhood to adolescence. Canadian Journal of Education, 32 (3), 558-590.

CEFR (2001). Common European framework of reference for languages: Learning, teaching, assessment. Council for Cultural Co-operation. Education Committee, Modern Languages Division, Strasbourg. Cambridge: Cambridge University Press.

Chamot, A. U. (2005). Language learning strategy instruction: Current issues and research. Annual Review of Applied Linguistics, 25, 112-130.

Coleman, J. et al. (1966). Equality of educational opportunity. Johns Hopkins University. https://files.eric.ed.gov/fulltext/ED012275.pdf

Davis-Kean, P. E. (2005). The influence of parent education and family income on child achievement: The indirect role of parental expectations and the home environment. Journal of Family Psychology, 19 (2), 294-304.

Dubow, E. F., Boxer, P. \& Huesmann, L. R. (2009). Long-term effects of parents' education on children's educational and occupational success: Mediation by family interactions, child aggression, and teenage aspirations. Merrill-Palmer Quarterly (Wayne State University. Press), 55 (3), 224-249. http://doi.org/10.1353/mpq.0.0030

Dörnyei, Z. \& Ushioda, E. (red.). (2011). Teaching and researching motivation. London: Routledge. 
Ellis, R. (2009). Task-based language teaching: Sorting out the misunderstandings.

International Journal of Applied Linguistics, 19 (3), 221-246.

Ellis, R. \& Shintani, N. (2014). Exploring language pedagogy through second language acquisition research. New York \& London: Routledge.

European Commission (2012). First European survey of language competences. Final report. http://ec.europa.eu/dgs/education_culture/repository/languages/policy/strategicframework/documents/language-survey-final-report_en.pdf

Finlex 11.6.1999/731. Finlands grundlag. http://www.finlex.fi/sv/laki/ajantasa/1999/19990731?search[type]=pika\&search[pika] $=731$

Gitomer, D.H. \& Zisk, R.C. (2015). Knowing what teachers know. Review of Research in Education, 39, 1-53. DOI: 10.3102/0091732X14557001.

Harjanne, P., Reunamo, J. \& Tella, S. (2015). Finnish foreign language teachers' views on teaching and study reality in their classes: The KIELO project's rationale and results. (report). Journal of Language Teaching and Research, 6 (5), 913-924.

Hattie, J. (2012). Visible learning for teachers: A maximizing impact on learning. London: Routledge.

Hildén, R. (2009). Transforming language curricula through a research and development project: A case from Finland. I T. Autio \& E. Ropo (red.), International conversations on curriculum studies (ss. 235-256). Sense Publishers.

Hildén, R., Härmälä, M., Rautopuro, J., Huhtanen, M., Puukko, M. \& Silverström, C. (2015). Outcomes of language learning at the end of basic education in 2013. Helsingfors: Finnish Education Evaluation Centre; Finnish National Board of Education. http://www.oph.fi/download/165161_outcomes_of_language_learning_at_the_end_of _basic_education_in_2013.pdf

Hildén, R. \& Rautopuro, J. (2014a). Ruotsin kielen A-oppimäärän oppimistulokset perusopetuksen päättövaiheessa 2013. [National evaluation of learning outcomes in Swedish language at the end of compulsory basic education 2013]. Helsingfors: Finnish Education Evaluation Centre. http://karvi.fi/publication/ruotsin-kielenoppimaaran-oppimistulokset-perusopetuksen-paattovaiheessa-2013 
Hildén, R. \& Rautopuro, J. (2014b). Venäjän kielen A-ja B-oppimäärän oppimistulokset perusopetuksen päättövaiheessa 2013. [National evaluation of learning outcomes in Russian language at the end of compulsory basic education 2013.] Helsingfors: Finnish Education Evaluation Centre. http://www.oph.fi/julkaisut/2014/venajan_kielen_a_ja_b_oppimaaran_oppimistulokset _perusopetuksen_paattovaiheessa_2013

Hildén, R. \& Rautopuro, J. (2014c). Saksan kielen A- ja B-oppimäärän oppimistulokset perusopetuksen päättövaiheessa 2013. [National evaluation of learning outcomes in German language at the end of compulsory basic education 2013.] Helsingfors: Finnish Education Evaluation Centre. http://karvi.fi/publication/saksan-kielen-ja-boppimaaran-oppimistulokset-perusopetuksen-paattovaiheessa-2013/

Hildén, R. \& Takala, S. (2007). Relating descriptors of the Finnish school scale to the CEF overall scales for communicative activities. I A. Koskensalo, J. Smeds, P. Kaikkonen $\&$ V. Kohonen (red.) Foreign languages and multicultural perspectives in the European context; Fremdsprachen und multikulturelle Perspektiven im europäischen Kontext. Dichtung, Wahrheit und Sprache (ss. 291-300). LIT-Verlag.

Huhta, A. \& Tarnanen, M. (2009). Assessment practices in the Finnish comprehensive school: What is the students' role in them? I LED2007: Refereed conference proceedings of the 2nd International Conference on Language, Education and Diversity. Hamilton, New Zealand: WMIER, University of Waikato.

Härmälä, M., Huhtanen, M. \& Puukko, M. (2014). Utvärderingen av inlärningsresultaten i Alärokursen i engelska våren 2013. Helsingfors: Nationella centret för utbildningsutvärdering.

Juurakko-Paavola, T. \& Palviainen, Å. (red.) (2011). Svenskan i den finska skolan och högre utbildningen: Om kunskaper och motivation genom olika utbildningsstadier.

Tavastehus: Hämeen ammattikorkeakoulu.

Kämppi, K., Välimaa, R., Ojala, K., Tynjälä, J., Haapasalo, I., Villberg, J. \& Kannas, L. (2012). Koulukokemusten kansainvälistä vertailua 2010 sekä muutokset Suomessa ja Pohjoismaissa 1994-2010. (HBSC-Study).

http://www.oph.fi/download/142520_Koulukokemusten_kansainvalista_vertailua_201 0_seka_muutokset_Suomessa_ja_Pohjoismaissa_1994-2010_WHO-

Koululaistutkimus_HBSC-Study_.pdf. 
Kärkkäinen, T. (2004). Koulutuksen ja lapsi-vanhempisuhteen yhteys elämässä selviytymiseen: Sosiaalinen perimä ja koulutuskulttuurisen pääoman periytyminen sukupolvesta toiseen. http://ethesis.helsinki.fi/julkaisut/kay/sovel/vk/karkkainen/

Lantolf, J. \& Thorne, S. L. (2006). Sociocultural theory and the genesis of second language development. Oxford: Oxford University Press.

Lehti-Eklund, H. \& Green-Vänttinen, M. (2011). Svenska i finska grundkolor. Nordica Helsingiensia 27. Helsingfors: Helsingfors universitet.

Livingstone, K. A. (2011). The effectiveness of a mixed methodology implemented in a beginner's Spanish course to develop the four language skills: A quasi-experimental study. Pragmalinguistica, 19, 56-78.

Long, M. H. (2015). Second language acquisition and task-based language teaching. West Sussex, England: John Wiley \& Sons.

Marczak, M. (2013). Communication and information technology in (intercultural) language teaching. Newcastle upon Tyne: Cambridge Scholars Publishing.

McNamara, T. F. \& Roever, C. (2006). Language testing: The social dimension. Malden: Blackwell.

Metsämuuronen, J. (2006). Tutkimuksen tekemisen perusteet ihmistieteissä (2 uppl.). Jyväskylä: Gummerus.

Miles, M. B., \& Huberman, A. M. (1994). Qualitative data analysis: An expanded sourcebook. Thousand Oaks, CA: Sage.

Nationella centret för utbildningsutvärdering (2014). Inlärningsresultaten $i$ språk $i$ årskurs 9 år 2013: Sammandrag. https://karvi.fi/sv/publication/inlarningsresultaten-sprakarskurs-9-ar-2013/

OECD (2015). PISA 2015 results. http://www.oecd.org/pisa/

Pica, T. (2005). Classroom learning, teaching, and research: A task-based perspective. Modern Language Journal, 89 (3), 339-352.

Rossi, P., Ainoa, A., Eloranta, O., Grandell, M., Lindberg, M., Pasanen, J., Sihvonen, A., Hakola, O. \& Pirinen, T. (2017). Kuka opettaa ruotsia? Ruotsin kielen opettamisen kelpoisuuden tuottavien koulutusten arviointi. [Vem undervisar i svenska? En 
utvärdering av utbildningar som ger behörighet att undervisa i svenska]. Nationella centret för utbildningsutvärdering.

Salmela-Aro, K. (2017). Dark and bright sides of thriving: School burnout and engagement in the Finnish context. European Journal of Developmental Psychology, 14 (3), 337349. DOI: 10.1080/17405629.2016.1207517.

Salmela-Aro, K. \& Tuominen-Soini, H. (2013). Koulu-uupumuksesta innostukseen? I J. Reivinen \& L. Vähäkylä (red.), Ketä kiinnostaa? Lasten ja nuorten hyvinvointi ja syrjäytyminen (ss. 242-254). Helsingfors: Gaudeamus.

Samuda, V. \& Bygate, M. (2008). Tasks in second language learning. Basingstoke: Palgrave Macmillan.

Sanchez, H. S. \& Borg, S. (2014). Insights into L2 teachers' pedagogical content knowledge: A cognitive perspective on their grammar explanations. System, 44, 45-53.

Schreier, M. (2014). Qualitative content analysis. I U. Flick (red.), The SAGE handbook of qualitative data analysis (ss. 170-183). London: SAGE Publications. DOI: http://dx.doi.org/10.4135/9781446282243.

Sirin, S. R. (2005). Socioeconomic status and academic achievement: A meta-analytic review of research. Review of Educational Research, 75 (3), 417-453.

DOI:10.3102/00346543075003417

Statistikcentralen (2017a). Finlands officiella statistik (FOS): Befolkningsstruktur [epublikation]. ISSN=1797-5387. 2015, Tabellbilaga 2. Befolkningen efter språk 19802015. Helsingfors: Statistikcentralen. http://www.stat.fi/til//vaerak/2015/vaerak_2015_2016-04-01_tau_002_sv.html

Statistikcentralen (2017b). Finlands officiella statistik (FOS): Ämnesval [e-publikation]. ISSN=1799-1048. Ämnesval bland elever i grundskolan 2015. Helsingfors: Statistikcentralen. http://www.stat.fi/til/ava/2015/02/ava_2015_02_2016-0524_tie_001_sv.html

Struyven, K., Dochy, F. \& Janssens, S. (2005). Students' perceptions about evaluation and assessment in higher education: A review. Assessment \& Evaluation in Higher Education, 30, 325-341.

Takala, S. (2012). Miten suomea ja ruotsia osataan äidinkielenä ja toisena kansalliskielenä peruskoulun ja lukion päättövaiheessa? http://kiesplang.fi/blog/wp- 
content/uploads/2011/10/Takala_Miten-suomea-ja-ruotsia-osataan-

\%C3\%A4idinkielen\%C3\%A4-ja-toisena-kansalliskielen\%C3\%A4-peruskoulussa-ja-

lukiossa_Kansalliskielistrategiaprojektille-laadittu-katsaus_2012.pdf

Thomas, W. \& Collier, V. (1997). School effectiveness for language minority students. NCBE Resource Collection Series, 9. Washington: George Washington University. http://www.thomasandcollier.com/assets/1997_thomas-collier97-1.pdf

Tudini, V. (2015). Interactivity in the teaching and learning of foreign languages: What it means for resourcing and delivery of online and blended programmes. The Language Learning Journal, 46 (2), 132-145. DOI: 10.1080/09571736.2014.994183

Tuokko, E. (2002). Perusopetuksen päättövaiheen ruotsin kielen oppimistulosten kansallinen arviointi 2001. Helsingfors: Utbildningsstyrelsen.

Tuokko, E. (2009). Miten ruotsia osataan peruskoulussa? Perusopetuksen päättövaiheen ruotsin kielen B-oppimäärän oppimistulosten kansallinen arviointi 2008. Helsingfors: Utbildningsstyrelsen. http://www.oph.fi/download/116603_miten_ruotsia_osataan_peruskoulussa.pdf.

Undervisnings- och kulturministeriet (2012). Toiminnallista ruotsia: Lähtökohtia ruotsin opetuksen kehittämiseksi toisena kotimaisena kielenä. Opetus- ja kulttuuriministeriön työryhmämuistioita ja selvityksiä 2012: 9. Helsingfors: Undervisnings- och kulturministeriet. https://julkaisut.valtioneuvosto.fi/handle/10024/75370

Undervisnings- och kulturministeriet (2017a). Monikielisyys vahvuudeksi: Toimenpideehdotukset Suomen kansallisen kielivarannon kehittämiseksi. Helsingfors: Undervisnings- och kulturministeriet.

Undervisnings- och kulturministeriet (2017b). Utredning om läget för och utvecklingsbehovet beträffande språkreserven i Finland offentliggjord. http://minedu.fi/artikkeli/lasset_publisher/selvitys-suomen-kielivarannon-tilasta-ja-kehittamistarpeistajulkaistu?_101_INSTANCE_0R8wCyp3oebu_languageId=sv_SE

Utbildningsstyrelsen (2004). Grunderna för läroplanen för den grundläggande utbildningen. Föreskrift 1/011/2004. Helsingfors: Utbildningsstyrelsen. 
Utbildningsstyrelsen (2014a). Grunderna för läroplanen för den grundläggande utbildningen. Föreskrifter och anvisningar 2014: 96. Helsingfors: Utbildningsstyrelsen.

Utbildningsstyrelsen (2014b). Inlärningsresultaten i språk $i$ årskurs 9 år 2013. Helsingfors: Utbildningsstyrelsen och Nationella centret för utbildningsutvärdering.

Van Lier, L. (1996). Interaction in the language curriculum: Awareness, autonomy and authenticity. London: Longman.

Van Lier, L. (2000). From input to affordance: Social-interactive learning from an ecological perspective. I J. P. Lantolf (red.), Sociocultural theory and second language learning (ss. 245-259). Oxford: Oxford University Press.

Virtanen, V., Postareff, L. \& Hailikari, T. (2015). Millainen arviointi tukee elinikäistä oppimista? Yliopistopedagogiikka, 22 (1), 1-11.

Vygotsky, L. S. (1982). Ajattelu ja kieli. (Övers. till finska av K. Helkama \& A. KoskiJännes). Espoo: Weilin Göös.

Waninge, F. (2015). Motivation, emotion and cognition: Attractor states in the classroom. I Z. Dörnyei, P. D. MacIntyre \& A. Henry (red.), Motivational dynamics in language learning (ss. 195-213). Bristol: Multilingual Matters.

Wrigglesworth, J. \& Harvor, F. (2017). Making their own landscape: Smartphones and student designed language learning environments. Computer Assisted Language Learning. DOI: 10.1080/09588221.2017.1412986

You, C., Dörnyei, Z. \& Csizer, K. (2016). Motivation, vision, and gender: A survey of learners of English in China. Language Learning, 66 (1), 94-123. 